\title{
Impact of Children's Emotional Influencing Strategies on Parental Purchasing Decision on Children's Food
}

\author{
Victor Monday Dibie \\ Email: v.dibie@gmail.com \\ Department of Marketing, College of Management Sciences, \\ Michael Okpara University of Agriculture, Umudike, Abia State, Nigeria.
}

\begin{abstract}
The study focused on impact of children's emotional influencing strategies on parental purchasing decision on children's food. The justification for the study was that it examined how emotional strategies help children to influence parental purchasing decision on children's food. The specific objective of the study was to examine the extent which children's emotional influencing strategies affect parents in purchasing food for their children. Survey research design was used. Out of the 400 respondents, 386(97\%) were considered valid and used. Simple percentage was used to analyze responses to structured questionnaire items. Multiple regression technique was used to test hypothesis. Results indicated that children's emotional influencing strategies have a significant effect on parental purchasing decision on children's food. A major recommendation was that manufacturers and marketers of children's food products should constantly study children's emotional behavior with a view to designing food products and communication campaign capable of meeting children's needs.
\end{abstract}

Keywords: Children, Children's food, Children's emotional influencing strategies, Parental purchasing decision.

Copyright: (c) 2021 Dibie V.M. This is an open access article distributed under the Creative Commons Attribution License, which permits unrestricted use, distribution, and reproduction in any medium, provided the original work is properly cited.

ORCID of Author: Dibie, V.M. - https://orcid.org/0000-0003-3402-7167

DOI: http://doi.org/10.4038/kjm.v10i1.7667 


\section{Introduction}

Basically, children and parents are the key components of a family. The family is a collection of people linked by blood, marriage or adoption and living together under the same roof (Loudon and DellaBitta, 1993). A family may be referred to as a single parent family, a stepparent family or an intact family. A family where a child is raised by only the father or mother is regarded as a single parent family (Kendig and Bianchi, 2008). Meanwhile, a family is referred to as a stepparent family where the parents raising the child are not the biological parents and different terms have been used to explain the meaning of stepfamily; some of these terms include repartnered families, remarried families and blended families (Cartwright and Gibson, 2012).

There are also different terms which were used to explain different types of stepfamilies. The simple stepfamilies are families where just a parent is having offsprings out of a former marriage (Ganong and Coleman, 2004). Meanwhile complex stepfamilies are families where the two parents have children from past marriages. Families with stepfathers are simple stepfamilies with a mother, her children and then the partner. Also, families with stepmothers are simple stepfamilies with a father, his children and then the partner. Meanwhile, a family is described as an intact family where the parents bringing up the child are the biological parents (Daniel, Qiuzhi and Li, 2015).

As members of the family, children have been categorized by various researchers and groups (Child Development Institute, 1999) as follows: Infants/Babies (0-2years); Toddlers/Preschoolers (2-5years); School Age Children (6-12years); and Adolescents/Teenagers (13-17years). For this study however, the focus was on children of school age (6-12years). The decision to focus on children within this age bracket was based on the assumption that such children are able to communicate with their parents effectively (Levickis, Reilly, Girolametto, Ukoumunne and Wake, 2014). Parents were however, relied on to provide relevant information concerning the children's request behaviour, through the use of a structured questionnaire, as they are custodians of the children.

In most families, it appears children naturally exert some influence on parental purchase decisions, for different products and product categories. The resulting effect of the direct or indirect show of power in this regard, which is the ability an individual exercises to change the character of some other people is what is referred to as influence (Corfman and Lehmann, 1987). The ways children influence parental purchases may be quite complex. McNeal (1998) asserts that such influence principally embraces products for children (snacks, clothes, consumer electronics, and hobbies); products for family use (furniture products, television and stereo sets; and food and beverages for family meals) and products not meant for general household use (holiday trips, cars, dressing materials, fastfood and recreation centres).

Impact of children within the family may possibly be felt at one point or the other in any of the various phases of the purchasing process: recognition of need, search for diverse information, assessment of alternatives, actual purchase; and post purchase analysis. The need recognition is the stage where a need arises and maybe triggered by internal or external stimuli to the buyer; this is followed by information search, the stage where the buyer searches for information intelligently from all possible sources that will lead to making the purchase decision; the next is the evaluation of alternatives, where the buyer evaluates alternative product/brand offerings in order to reach a purchase decision, where the actual purchase is carried out and payment made; the last stage is the post purchase behavioural exhibition where the buyer's behaviour shows whether he is satisfied or dissatisfied (Nwokoye, 2000). 
The level of influence wielded by children on parental purchasing decision may be governed by different factors/strategies across different products/product categories. However, this work centered on the impact of children's emotional influencing strategies on parental purchasing decision on children's food. Food is any substance consumed for the purpose of providing nutritional support for the body. However, the food items referred to in this work were snacks and drinks (juices) children demand for regularly. A strategy in this respect is the exact behavior a child skillfully exhibits at a particular point to influence the purchasing decision of the parents for a particular product or product category. Meanwhile, children adopt different strategies at different times to influence parental purchasing decision for different products or product categories. Specifically, this work examined children's emotional influencing strategies as the independent variables, mirrored by crying, panting, pouting, social withdrawal and silent treatment with parental purchasing decision on children's food as the dependent variable.

For purposes of clarity, in the context of this work, the strategies are defined as follows: crying is the outpouring of tears by children when they need food urgently; panting is the display of anger by children when food is not available; pouting is the exhibition of intense anger by children when there is a prolonged delay in the approval of their requests for food; social withdrawal is the intentional withdrawal from family activities and members by children as a result of anger for lack of food; and silent treatment is the expression of moodiness by children to blackmail their parents in order to get their requests for food approved.

\section{Statement of the Problem}

There seems to be a practice gap in our system. Some household products are meant to meet the specific needs of children, but it appears that almost all major activities of firms target only parents and other adults whom they feel can easily make or influence purchasing decisions in favour of their products. Children in this regard appear to be relegated to the background, not considering the fact that purchasing decisions parents and other adults in the family make could be influenced by children, either directly or indirectly (Arul and Vasudevan, 2016). Therefore, if children could influence purchasing decisions for some household products, it becomes pertinent for firms to know the extent children could go or contributions children could make as well as the strategies they could adopt in the process of influencing purchasing decisions for such household products. So, as active members of the family, children sometimes feel they have been denied their rightful places in the family purchasing decision making process. In this regard, children tend to adopt different strategies to influence parental purchasing decisions for children's products, to feel a sense of belonging immediately they develop skills to present their request to parents on products that appeal to them (Omodafe, 2015).

Meanwhile, previous authors have identified the use of emotion-based strategies by children to express mode or state (Miceli and Castelfranchi, 2003; Potegal and Davidson, 2003; Magher, 2015; Fox, Henderson, Marshall, Nicolas, and Ghera, 2005; Lehman, 2010). It appears however that nothing much has been done in the area of how children use emotional strategies to influence parental purchasing decision in terms of literature and provision of concrete empirical evidence. In this regard, the justification for this study was that it examined how children use emotional strategies mirrored by crying, panting, pouting, social withdrawal and silent treatment to influence parental purchasing decision for children's food. Findings from the study would be of great significance in terms of helping to build sustainable relationships among parents and children and among firms and families. 


\section{Objective of the Study}

The specific objective of the study was to examine the extent which children's emotional influencing strategies affect parents in purchasing food for their children.

\section{Research Question}

The key research question for this study is stated as follows:

What extent children's emotional influencing strategies affect parents in purchasing food for their children?

\section{Research Hypothesis}

The following hypothesis was tested in the course of this study:

$\mathrm{H}_{01}$ : children's emotional influencing strategies do not significantly affect parents in purchasing food for their children.

\section{Conceptual Review}

\section{Children's Emotional Influencing Strategies on Parental Purchasing Decision}

The use of emotional influencing strategies (crying, panting, pouting, withdrawing or giving the silent treatment) by children was identified by Lee and Collins (2000). Children tend to use them sometimes to express their mood in order to attract parental attention (Micelli and Castelfranchi, 2003; Magher, 2015). Crying means out pouring of tears to respond to a state of emotional imbalance. Crying is also described as a secretomotor situation which is showcased by out pouring of tears from the lacrimal apparatus. The physiological system containing the orbital structures for tear production and drainage involving no invitation of the ocular structure is what is referred to as the lacrimal apparatus (Patel, 1993). Crying can as well imply weeping, wailing, whimpering and blubbering. However, for crying to imply sobering, it has to go with a set of other symptoms like slow but erratic inhalation, occasional instances of breadth holding and insular tremor.
In this regard, inhalation is the drawing of substance (air) into the lungs (Passali, Lauriello, Bellussi, Passali, Passali and Gregori, 2010) while tremor is an involuntary act, like a rhythmic muscular contraction and relaxation, involving oscillations or twitching movement of one or more body parts. In fact, it is considered as the most common involuntary movement which can affect the hands, legs, arms, eyes, face, head, etc. (Deuschi, Bain, Brin and Adhoc Scientific Committee, 1998). Crying and weeping involve shedding of tears; to cry more strongly is to cry aloud but wail primarily refers to sustained, inarticulate mournful sound; and whimpering implies low, plaintive, broken or repressed cries as those made by a child while sobering explains weeping or a mixture of broken speech and weeping, followed by aggressive breathing or gasping; blubbering implies noisy unrestrained shedding of tears going with broken or inarticulate speech; there is a neuronal link joining the tear duct (lacrimal gland) with the portion of the human brain relating to emotion (Walter, 2006; Langseth, Freys and Willian, 1985). Scientists are now debating to arrive at a conclusion whether human beings only or other animals also produce tears while responding to certain un-conducive emotional states (ibid).

Crying could be caused by several factors. Theories include simple factors like responding to pains to the more complex factors like non-verbal communications in order to elicit altruistic behaviour from others (Human Ethology Newsletter, 1989). Altruistic behaviour relates to welfare or assistance from people. Some have discovered that crying serves various biochemical functions like the relie of stress and the release of toxins from the body (Doheny, 2011). Moreover, crying is also seen as a means of expressing intense emotional sensation like joy, surprise and even agony. This may be the reason why people cry during celebrations and during mourning as well (Frey, 1985). Again, crying can also be used to express one's helpless state as in children and adults, 
hence researchers have associated crying with a state of helplessness (Miceli and Castelfranchi, 2003). It is believed that when children find themselves in a state of confusion and perpetual helplessness when they need food they break loose in emotions and the result is crying. In most families in Southeast Nigeria, a child may not have planned to cry on a particular Sunday morning, as everybody is preparing for church, but may begin to cry as soon as he observes that his biscuit is not there; after crying for some minutes and nobody shows any attention towards getting the biscuit, he may resort to panting, pouting, withdrawing or giving the silent treatment and may remain there till someone comes to his rescue by providing the biscuit or else he may sleep off or not join the family to church again that day (Dibie, 2017). See Appendix A (Image of Children Crying).

Panting is breathing hard and quickly as after exertion, with the tongue hanging out like that of a dog (MedHelp, 2000). Panting among children expresses tamper tantrum. In this regard, a tantrum, tamper tantrum, meltdown or hissing fit is a way of expressing emotional distress especially among children and is characterized with intense anger. At this point all manner of control may not calm the child down until his goal of getting the food he needs is achieved (Davidson, 2006; Leikin and Lipsky, 2003; McCurdy, Kunz and Sheridan, 2006; Potigal and Davidson, 2003). While tantrums are sometimes considered as a predictor of future antisocial behaviour (Potegal and Davidson, 2003), in another sense they are simply an age appropriate sign of excessive frustration which disappear with time when properly handled (Roy, 2008). So, tantrums form one of the common problematic behavioural exhibitions among children, which tend to gradually go out of children as they grow older. Meanwhile, parental containment where a child cannot contain himself, rather than what the child is constantly asking for may be what is really required (Casement, 1990). See Appendix B (Images of Children Panting).
Pouting is having the lips sticking out, usually to show the annoyance in the child. Pouting is a common reaction observed among children when they get angry or feel neglected. Though pouting is more common among younger children, older children and even teenagers these days resort to pouting when they are upset. One important fact to note here is to understand what causes children to pout, which is the first step in learning how to address this worrisome behavior (Magher, 2017). Pouting is common among young children due to several factors one of which is lack of intelligence to express themselves in a healthy way (Magher, 2015). Following their age, children may not have acquired the right language or vocabulary to express themselves or their feelings when they feel they have waited for food for too long; and may not even be able to recognize their feelings. Based on these, they may just begin to feel upset, sad, frustrated and angry which may include pouting. Meanwhile, one of the ways to reduce pouting and other troubling behaviours among children is helping them learn how to express their feelings. It is also important to state here that older children who may have acquired the right language to express their feelings may not be able to do so, when they feel they do not have the right outlet to voice out. So, a second factor responsible for pouting among children is when they cannot communicate. In this regard, children under the control of very strict or autocratic parents or guardians who may not feel safe expressing their feelings freely may simply resort to pouting; another factor that reasonably accounts for children pouting is when they feel they are not given enough attention. Sometimes, older children even pout when they need special attention which is not forthcoming. Parents are therefore advised to spend more one-on-one time with their children and quality time with family members. Finally, most children use pouting to manipulate parents when they have studied their parents carefully and found out that pouting attracts good results, in terms of 
helping them get what they want from their parents, and in such situations they pout more often (Lehman, 2010). See Appendix C (Images of Children Pouting)

The expression of social withdrawal by children according to some researchers can be a way of expressing themselves when they are sad (Fox et al, 2005) especially for not having the food they need. For some, withdrawal may be seen as a symptom of the child's isolation, exclusion or even peers' rejection (Boivin, Hymel and Bukowski, 1995; Gazelle and Ladd, 2003). Again, there are other groups that assume the lack of a social approach and a preference for object manipulation and construction over interpersonal exchange result from children's withdrawal (Coplan, Prakash, O’neil and Armer, 2004). Finally, another group exists that assume the social withdrawal of children is connected with psychological maladaptation showing display of internalized thinking and feelings of fear or depression (Vasa and Pine, 2006). Social withdrawal may however be approached by different children in different ways for different reasons. However, the extent to which social withdrawal can help the child get his purchase request granted is critical to this study. See Appendix D (Images of Children Withdrawing).

The silent treatment is used by children as a way to freeze you out to get you to leave them alone (Lefman, 2010). In this regard, children tend to express moodiness to blackmail the parents in order to get them to approve their requests for food. What most parents fail to understand most times when a child gives them the silent treatment is that something is going on under the surface. The silent treatment is giving the child a feeling of power and control over the parents; usually, children give their parents the silent treatment when they are angry or embarrassed. A child may even be giving the parents the silent treatment when he has done something wrong and knows it. Children with narcissism intelligently use the silent treatment to blackmail or abuse parents emotionally (Schneider, 2014). One fact about the silent treatment of children is that the more the parents demonstrate a behaviour that shows the action of the child is painful to them the more the child would use it to get to them; it is however important for parents to realize that when a child is giving the silent treatment, that is probably the best problem-solving strategy he has at that moment, which he tries to use in dealing with the issue at hand; so, by refusing to talk or pass any information or thoughts the child has found a way of getting an upper hand over the parents; this kind of silent aggressiveness may be quite destructive to relationships in the future, hence most parents would not want to easily give in to it or reward it in their children (Pietrangelo, 2019). There are six rules that can guide parents in handling the silent treatment of children: "the first rule is that parents should not get into ego struggle with the child because that would simply give the child more opportunity to assume more powers, parents should therefore find a soft way of addressing the problem and remain in control. The second rule is that parents should let the child know clearly that the silent treatment would not address the problem, but that their readiness to talk and help their parents find ways of addressing the problem would help solve the problem. The third rule is that parents would reach out to the child at once and where he persists, they let him be, as reaching out to him more than once gives him more powers. The fourth rule is that parents should completely cease to respond to the silent treatment as that would naturally kill it. The fifth rule is that parents should not descend to the level of the child by resorting to any form of argument or returning same behaviour of silent treatment to the child. Parents should rather try something else that is more effective. The sixth and the last rule is that parents should make participation in family life a requirement" (Lehman, 2010). Young people go through a stage where they develop a kind of contempt for family living and it can be easily observed in them. Well- 
behaved children can be more passive about this kind of behaviour. The very natural thing to do to stop the silent treatment is that parents should not give it any power. See Appendix E (Images of Children's Silent Treatment).

\section{Framework for the Study}

\begin{tabular}{|c|c|}
\hline $\begin{array}{l}\text { Children's Emotional } \\
\text { Influencing Strategies }\end{array}$ & \\
\hline$\frac{1}{1}$ & \\
\hline Crying & \\
\hline Panting & Parental Purchasing \\
\hline Pouting & Food \\
\hline $\begin{array}{c}\text { Social } \\
\text { Withdrawal }\end{array}$ & Dependent Variable \\
\hline
\end{tabular}

Figure 7 describes the researcher's conceptualization of the relationship between children's emotional influencing strategies and parental purchasing decision on children's food as represented by the model: PPDF = $\mathrm{f}(\mathrm{EmS})$.

Where:

PPDF $=$ Parental Purchasing Decision on Children's Food

EmS $=$ Emotional Influencing Strategies of Children

The model shows that parental purchasing decision on children's food is a function of children's emotional influencing strategies. It was on this premise the hypothesis of the study was built.
Ho: Children's emotional influencing strategies do not significantly affect parents toward purchasing food for their children

\section{Theoretical Framework}

The Social Cognitive Theory supported this study

The social cognitive theory was developed by Albert Bandura in 1986 . The theory was developed after a critical review of the original theory of social learning and imitation proposed by Miller and Dollard in 1941 in the USA and other related theories later developed including his earlier theories and observed the noninclusion of critical elements (Pajares, 2002). 


\section{The Social Cognitive Theory}

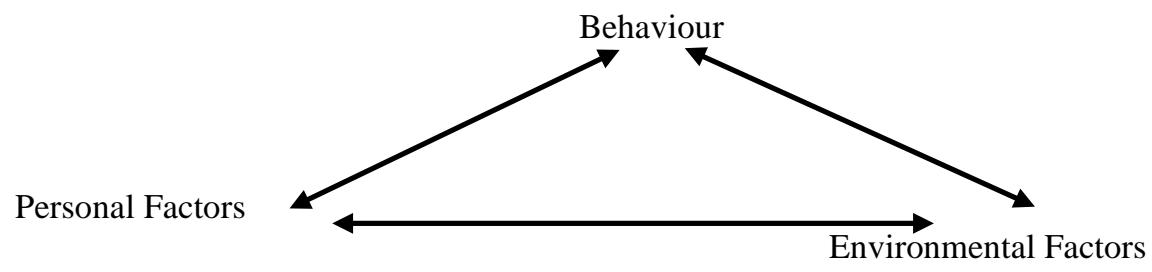

Source: Pajares (2002).

The social cognitive theory was developed by Albert Bandura in 1986. The theory was developed after a critical review of the original theory of social learning and imitation proposed by Miller and Dollard in 1941 in the USA and other related theories later developed including his earlier theories and observed the non-inclusion of critical elements (Pajares, 2002). The theory examines the cognitive, emotional aspects and other critical aspects of behaviour that make the understanding of behaviour changes especially with children easy and provides opportunities for modern behavioural research in consumer education and health. It also provides ideas for new insights in aspects of psychology relevant to consumer studies. Finally, the theory examines how people achieve and sustain some basic behavioural traits and also provide basis for interventionist strategies (Bandura, 1997). Evaluating changes in consumer behaviour hangs on factors like environment, people and behaviour. An acceptable framework for the designing, implementation as well as evaluation of programmes has been provided by the Social Cognitive Theory. Environment in this context is referring to factors that can reasonably affect an individual's behaviour, which are categorized into social and physical environments.

Family members, friends and colleagues make up the social environment whereas the physical environment can be the size of the house or room, the ambient temperature or the ability of some food. Environment and situation as opined by Parraga (1990) gives the framework for understanding behaviours. The issue here talks about the cognitive or mental representations of the environment that may have effects on the behaviour of an individual. The issue can be the perception of an individual in terms of place, time, physical features and activity (Glanz, et.al., 2002). The environment as in the case of children, provides models for behaviour. Observational learning results as a child observes another child's actions and the reinforcements that the child gets (Bandura, 1997).

Glanz et.al. (2002) highlighted the basic concepts relating to the Social Cognitive Theory as follows:

i. Environment: Factors physically extended to an individual which help to provide opportunities and social support.

ii. Situation: Perception of the environment; correct misperceptions and promote healthful forms

iii. Behavioural Capability: Knowledge and skill to exhibit a particular behaviour promote mastery learning through effective skills acquisition and training.

iv. Expectations: Anticipatory outcomes of a particular behaviour; model positive outcomes of healthful behaviour.

v. Expectancies: The values that an individual places on a given outcome/incentives, present outcomes of change that have functional applicable meanings.

vi. Self-Control: Personal regulation of goal directed behaviour or performance of the individual provide opportunity for selfmotivation, goal setting, problem solving and self-reward. 


\section{vii. Observational}

Learning: Behavioural requisition which results through watching actions and outcomes of others including credible role models of the behaviour targeted.

viii. Reinforcement: Responses to the behaviour of an individual that affect the probability of reoccurrence, promote self-initiated rewards and incentives.

ix. Self-Efficacy: The confidence of an individual while exhibiting a specific behaviour; approach behavioural change gradually, (in small attempts) to achieve success.

x. Emotional Coping Responses: Strategies and tactics and emotion related stimuli, provide opportunities for solving problems and effectively managing stress.

xi. Reciprocal determinism: The dynamic intervention of the individual, the behaviour and environment in which the behaviour is exhibited; consider multiple opportunities to behavioural change, including environment, skill and personal change.

\section{Empirical Review}

The studies considered relevant to this study were reviewed as follows:

The study carried out by Chaudhary and Gutpta (2012) in India identified and ranked the different influencing strategies of children and examined the parent-child perceptual differences with regard to using the different influencing strategies. Through using a structured questionnaire, a survey involving 200 children of 8-12yrs and their parents (father or mother) was carried out. In total, 400 responses were collected at out which 350 (175 children and 175 parents) were observed to be fully completed representing $87.5 \%$. The remaining 50 were discarded based on inconsistencies. Results from the study identified and ranked the influencing strategies mostly used by children of this age group as follows: $\left(1^{\text {st }}\right)$ persuasive strategy, $\left(2^{\text {nd }}\right)$ emotional strategy, $\left(3^{\text {rd }}\right)$ bargaining strategy. There were no much differences found between parent and child perception concerning the use of different influencing strategies. However, the study did not specifically identify crying, panting, pouting, social withdrawal and silent treatment as emotional strategies of children.

The study carried out by Omodafe (2015) in Asaba, capital city of Delta State, Nigeria, examined children's role on buying decisions in the family and investigated factors that affect the involvement level of children in family buying decision making. Copies of the questionnaire used were randomly distributed to 218 children of 5-16 years out of which 200 copies were recovered (92\%). 48 parents were also interviewed. Data generated were analysed using simple descriptive statistics, multiple regression and Analysis of Variance (ANOVA). Results from the study (among others) revealed that children's influence on parental buying decisions for products that appeal to children's interests and emotions is relatively high; children's influence on parental buying decisions for highly technical and economic products is relatively low; children's involvements in family buying decisions are affected by demographic, cultural and economic factors; rapid changes in the study area (Asaba) from a local town to a popular capital city have increased children's role in the family decision making process. However, the study did not specify the actual emotional or other strategies children adopt to influence parental purchasing decision.

\section{Methodology}

Survey design was used in this study. It gave room for the use of questionnaire to generate relevant data to treat the variables in the study. The study was carried out in Umuahia, Abia State, Southeast, Nigeria. Umuahia is composed of two Local Government Areas, Umuahia North and Umuahia South, with headquarters in Ibeku and Ubakala respectively. (Federal Republic of Nigeria Official Gazette, 2007). The population of the study was composed of parents having children or wards of ages 612 years who could communicate with them 
through the application of different strategies while making purchase requests for children's food products.

The study population was 115,$934 ; 71,303$ from Umuahia North and 44,631 from Umuahia South (NPC, 2006).
The sample size of 400 was determined with the Yamane (1967) sample size determination formula:

$$
n=\frac{N}{1+N(R)^{2}}
$$

Figure 8: Sample Size Determination Formula

Source: Yamane (1967)

\begin{tabular}{|c|c|c|c|c|}
\hline Where & $\mathrm{n}$ & $=$ & ? & \\
\hline & $\mathrm{N}$ & $=$ & Study Population & $=$ \\
\hline & 115,934 & & & \\
\hline & 1 & $=$ & Constant & $=$ \\
\hline & $\mathrm{R}$ & $=$ & Error Margin (5\%) & $=$ \\
\hline & $(0.05)^{2}$ & $=0.0025$ & & \\
\hline
\end{tabular}

Cluster sampling technique was initially used to select areas with enlightened people assumed to be married and had children and wards of ages 6-12yrs. Thereafter, respondents for the study based on the sample size were selected through the simple random sampling technique. Results were however based on 386 completed and returned copies of the questionnaire. The Statistical Package for Social Sciences (SPSS 22.0 Version) was used to carry out the analysis and results interpreted appropriately.

The questionnaire contained structured statements based on the objective of the study. The questionnaire contained closeended statements related to the specific objective of the study using the Likert Scale rating of 1-5 to rate the responses as follows: Great Extent (GE) = 5; Considerable Extent $(\mathrm{CE})=4$; Moderate Extent $(\mathrm{ME})=3$; Little Extent $(\mathrm{LE})=2$; and Slight Extent $(\mathrm{SE})=1$. The questionnaire was validated by two experts in measurement and evaluation and one in marketing. The reliability coefficient of the instrument was ascertained using the Cronbach's Alpha. For research purposes, Wallen and Fraenkel (2001) view the coefficient alpha of 0.70 as acceptable; while DeVellis (1996) views the coefficient alpha below 0.65 as unacceptable. For purposes of this study, based on the above assertions, the acceptable coefficient alpha for this study is above 0.65. The Cronbach's Alpha of 0.99 was obtained showing a high degree of reliability of the instrument.

Table 1: Reliability Test

Processing Summary for Reliability Test

\begin{tabular}{|ll|c|c|}
\hline & & $\mathrm{N}$ & $\%$ \\
\hline Cases & Validated & 38 & 100.0 \\
& Excluded $^{\mathrm{a}}$ & 0 & .0 \\
& Total & 38 & 100.0 \\
\hline
\end{tabular}

a. Listwise deletion based on all variables in the procedure. 
Reliability Statistics for Reliability Test

\begin{tabular}{|c|c|c|}
\hline & Cronbach's Alpha Based & \\
on Standardized Items & N of Items \\
\hline .993 & .993 & 38 \\
\hline
\end{tabular}

Source: Researcher’s Estimation, (2016)

\section{Model}

\section{Specification}

In this study, the descriptive statistics (frequency counts and means score) were used to analyze data from respondents on children's emotional influencing strategies on parental purchasing decision on The modified model used for the study is thus presented as follows:

$$
\text { PPDF } \quad=\quad f\left(E_{\mathrm{m} .} S\right)
$$$$
\text { PPDF }=b_{0}+b_{1} \mathrm{C}+
$$

$\mathrm{b}_{2} \mathrm{PA}+\mathrm{b}_{3} \mathrm{PO}+\mathrm{b}_{4} \mathrm{~W}+\mathrm{b}_{5} \mathrm{ST}+$ ei (Dibie, 2017)

Where: MRT = $\quad$ Multiple

Regression Technique

PPDF = Parental

Purchasing Decision on Children's Food

$$
\mathrm{f} \quad=\text { "Function of" }
$$

Em.S = Emotional

Influencing Strategies of children

bo

$$
=\text { Constant }
$$

\section{Results}

In this section, primary data on emotional influencing strategies of children (crying, panting, pouting, social withdrawal, and silent treatment) on parental purchasing decision on children's food generated from respondents for purposes of calculating the children's food. Meanwhile, the multiple regression technique: $\mathrm{Y}=\mathrm{b}_{0}+\mathrm{b}_{1} \mathrm{x}_{1}+\mathrm{b}_{2} \mathrm{X}_{2}+$ $\mathrm{b}_{3} \mathrm{x}_{3}+\ldots .+\mathrm{b}_{\mathrm{n}} \mathrm{x}_{\mathrm{n}}$ (Tusian and Thunjhnuwala, 2010) was considered relevant and modified to suit the variables of the study.

$\begin{array}{lll} & \mathrm{b}_{1} & =\text { Coefficient of } \\ \mathrm{C} & (\mathrm{C}=\text { Crying }) \\ & \mathrm{b}_{2} & =\text { Coefficient of } \\ \mathrm{PA} & (\mathrm{PA}=\text { Panting }) \\ & \mathrm{b}_{3} & =\text { Coefficient of } \\ \text { PO } & (\mathrm{PO}=\text { Pouting } \\ & \mathrm{b}_{4} & \\ \mathrm{~W} & (\mathrm{~W}=\text { Withdrawing })\end{array}$ ST

$\mathrm{b}_{5} \quad=$ Coefficient of (ST= Silent Treatment)

ei $=$ Error Margin

mean scores are presented in tables 2 and 3. Meanwhile, results of the test of hypothesis are presented in table 4 . The tables were designed to allow a structured statement measure a particular variable to ensure all the variables were appropriately measured. 
Table 2: Analysis of Children’s Emotional Influencing Strategies (Item by Item) on Parental Purchasing Decision on Children's Food

\begin{tabular}{|c|c|c|c|c|c|c|c|c|}
\hline S/No & Item & $\begin{array}{c}\text { GE } \\
5 \\
\end{array}$ & $\begin{array}{c}\mathrm{CE} \\
4 \\
\end{array}$ & $\begin{array}{c}\text { ME } \\
3 \\
\end{array}$ & $\begin{array}{c}\text { LE } \\
2 \\
\end{array}$ & $\begin{array}{c}\text { SE } \\
1\end{array}$ & $\begin{array}{r}\text { TO } \\
\text { TAL }\end{array}$ & $\begin{array}{l}\text { MEAN } \\
\text { SCORE }\end{array}$ \\
\hline 1. & $\begin{array}{l}\text { The crying of children when } \\
\text { they need snacks and juices } \\
\text { make their parents to purchase } \\
\text { the products for them quickly. }\end{array}$ & $\begin{array}{c}231 \\
115 \\
5\end{array}$ & $\begin{array}{c}97 \\
388\end{array}$ & $\begin{array}{l}30 \\
90\end{array}$ & $\begin{array}{l}21 \\
42\end{array}$ & $\begin{array}{l}7 \\
7\end{array}$ & $\begin{array}{c}386 \\
1682\end{array}$ & 4.358 \\
\hline 2. & $\begin{array}{l}\text { Parents are moved to grant their } \\
\text { children's requests for snacks } \\
\text { and juices when they see their } \\
\text { children panting for lack of the } \\
\text { products. }\end{array}$ & $\begin{array}{l}199 \\
995\end{array}$ & $\begin{array}{l}167 \\
668\end{array}$ & $\begin{array}{c}7 \\
21\end{array}$ & $\begin{array}{c}7 \\
14\end{array}$ & $\begin{array}{l}6 \\
6\end{array}$ & $\begin{array}{c}386 \\
1704\end{array}$ & 4.415 \\
\hline 3. & $\begin{array}{l}\text { Children use pouting to draw the } \\
\text { attention of their parents after a } \\
\text { prolonged delay in granting their } \\
\text { requests for snacks and juices. }\end{array}$ & $\begin{array}{l}187 \\
935\end{array}$ & $\begin{array}{l}163 \\
652\end{array}$ & $\begin{array}{l}23 \\
69\end{array}$ & $\begin{array}{l}13 \\
26\end{array}$ & - & $\begin{array}{c}386 \\
1682\end{array}$ & 4.356 \\
\hline 4. & $\begin{array}{l}\text { Parents make quick moves to } \\
\text { grant their children's requests } \\
\text { for snacks and juices when they } \\
\text { observe their children } \\
\text { withdrawing from family } \\
\text { activities and members for lack } \\
\text { of the products. }\end{array}$ & $\begin{array}{l}195 \\
975\end{array}$ & $\begin{array}{l}107 \\
428\end{array}$ & $\begin{array}{c}63 \\
189\end{array}$ & $\begin{array}{l}19 \\
38\end{array}$ & $\begin{array}{l}2 \\
2\end{array}$ & $\begin{array}{c}386 \\
1632\end{array}$ & 4.228 \\
\hline 5. & $\begin{array}{l}\text { When children decide to stay } \\
\text { silent and lonely parents act fast } \\
\text { to change their mood by granting } \\
\text { their requests for snacks and } \\
\text { juices. }\end{array}$ & $\begin{array}{c}203 \\
101 \\
5\end{array}$ & $\begin{array}{l}109 \\
436\end{array}$ & $\begin{array}{c}69 \\
207\end{array}$ & $\begin{array}{c}5 \\
10\end{array}$ & - & $\begin{array}{c}386 \\
1668\end{array}$ & 4.321 \\
\hline
\end{tabular}

Source: Field Survey (2016)

Table 3: Analysis of Children's Emotional Influencing Strategies (En Bloc) on Parental Purchasing Decision on Children's Food

\begin{tabular}{clccccccc}
\hline S/N & \multicolumn{1}{c}{ Items } & GE & $\mathbf{C E}$ & $\mathbf{M E}$ & $\mathbf{L E}$ & $\mathbf{S E}$ & TOTAL & MEAN \\
& & $\mathbf{5}$ & $\mathbf{4}$ & $\mathbf{3}$ & $\mathbf{2}$ & $\mathbf{1}$ & & SCORE \\
\hline 6. & $\begin{array}{l}\text { Emotional strategies } \\
\text { of children make }\end{array}$ & 197 & 87 & 69 & 27 & 6 & 386 & 4.145 \\
& $\begin{array}{l}\text { parents to purchase } \\
\text { food for their children }\end{array}$ & & & & & & & \\
\hline
\end{tabular}

Source: Field Survey (2016) 


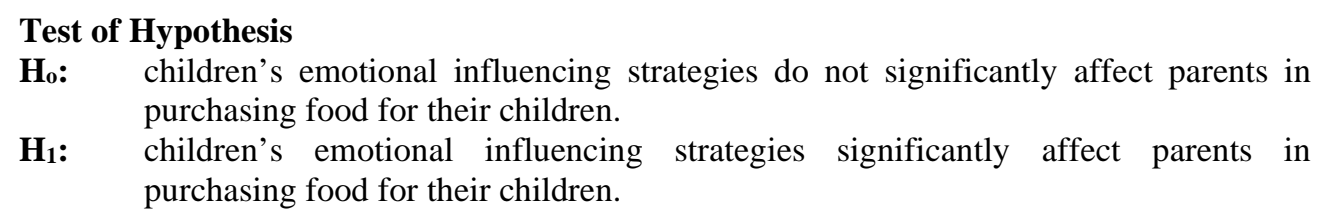
Table 4: Regression Results for Children's Emotional Influencing Strategies on Parental Purchasing Decision on Children's Food Coefficients $^{\mathbf{a}}$

\begin{tabular}{ccccccc}
\hline \multirow{2}{*}{ Model } & \multicolumn{2}{c}{ Unstandardized Coefficients } & $\begin{array}{c}\text { Standardized } \\
\text { Coefficients } \\
\text { Beta }\end{array}$ & $\mathrm{t}$ & Sig. \\
& & $\mathrm{B}$ & Std. Error & .429 & & \\
\hline \multirow{4}{*}{1} & (Constant) & .686 & .143 & .046 & .335 & .738 \\
& C & .048 & .114 & .222 & 2.185 & .029 \\
& PA & .248 & .057 & .939 & 19.515 & .000 \\
& PO & 1.104 & .141 & -.142 & -1.104 & .270 \\
& W & -.156 & .117 & -.270 & -2.413 & .016
\end{tabular}

Dependent Variable: PPDF

\begin{tabular}{llr} 
R & $=$ & .824 \\
R-Square & $=$ & .680 \\
Adjusted R-Square & $=$ & .675 \\
SEE & & .94034 \\
F-Statistic (df1=5 \& df2=380) & $=$ & 161.135 \\
Durbin Watson Statistic & $=$ & 2.005 \\
\hline Source: Researcher's Estimation (2016)
\end{tabular}

\section{Discussions}

Table 4 shows the regression results for children's emotional influence strategies on parental purchase decision making for children's food. The regression results indicated that the estimated coefficient of the regression parameter has both negative and positive signs and thus conform to our a-priori expectation. The coefficient of determination R-square of 0.680 implied that 68 percent of the sample variation in the dependent variable, parental purchase decision making for children's food (PPDF) is explained or caused by the explanatory variable while 32 percent is unexplained. This remaining 32 percent could be caused by other factors or variables not built into the model. The fairly high value of R-square is an indication of a good relationship between the dependent variable parental purchase decision making for children's food (PPDF) and the independent variable, children's emotional influence strategies crying, panting, pouting, withdrawing and silent treatment (C, PA, PO, W \& ST). The value of the adjusted $R^{2}$ is 0.675 . This shows that the regression line which captures 67.5 percent of the total variation on parental purchase decision making for children's food (PPDF) is caused by variation in the explanatory variable specified in the model with 32.5 percent accounting for the error term. The f-statistic was also used to test the overall significance of the model. The f-value of 161.135 is an indication that the model is statistically significant at 5 percent level of significance at degree of freedom $\mathrm{df} 1=5$ and $\mathrm{df} 2=380$. Finally, the test of autocorrelation using Durbin Watson (DW) test showed that the DW value of 2.005 falls within the 
conclusive region of DW partition curve. So, it can be clearly said that there is no degree of autocorrelation in existence.

With reference to table 4 the f-statistic value was $161.135(\mathrm{p}=.000)$. This implies that the null hypothesis is rejected and the alternative accepted, meaning children's emotional influencing strategies significantly affect parents in purchasing decision on children's food. From the analysis, this study indicated that the estimated coefficients of the regression parameter have both positive and negative signs and thus conform to our a-priori expectation. The implication of these signs is that the dependent variable, parental purchase decision making is both positively and negatively affected by the independent variables mirrored bycrying, panting, pouting, social withdrawal and silent treatment. The study also revealed that there is a very strong relationship between the dependent variable (parental purchase decision making) and the independent variable, mirrored by crying, panting, pouting, social withdrawal and silent treatment.This result is in agreement with the work of Omodafe (2015), who observed that children's influence on parental buying decisions for products that appeal to children's interests, and emotions is relatively high.

\section{Conclusion and Recommendations}

Children generally have been recognized as dominant influencers in family purchase decision making as their level of involvement in the purchase decision making process in modern families tend to be on the increase. Children exercise influence on family purchase decision making especially for products that appeal to their interests and emotions. So, children adopt different emotional strategies (crying, panting, pouting, social withdrawal and silent treatment) to influence parental purchasing decision on children's food. This conclusion is partly in agreement with the results of the study carried out by Chaudhary and Gupta (2012) in India that identified and ranked emotional strategy as one of the mostly used influencing strategies by children. The conclusion is also partly in agreement with results of the study carried out by Omodafe (2015) in Asaba, Nigeria that children's influence on parental buying decisions for products that appeal to children's interests and emotions is relatively high; children's influence on parental buying decisions for highly technical and economic products is relatively low; children's involvements in family buying decisions are affected by demographic, cultural and economic factors, among others.

The overall marketing implication in all of these is that children's involvement in family purchase decision making help manufacturers and marketers to identify specific product needs of different consumer groups including children and parents through effective segmentation for enhanced marketing operations.

Based on the findings and conclusion, it is recommended that manufacturers and marketers of children's food products should constantly study children's emotional behavior with a view to designing food products and communication campaign capable of meeting children's needs. Parents should carefully study the emotional/behavioural exhibitions of their children to know when they are rational and when they show mischief and respond appropriately. They should also learn how to appropriately handle children's emotional/behavioural exhibitions to prevent them from degenerating to dangerous levels. As children gradually get older and begin to communicate, parents should involve them in purchasing decisions for items like food that concern them. 
Dibie, V.M., KJM, 2021, 10 (01)

\section{Appendices}

\section{Appendix A}

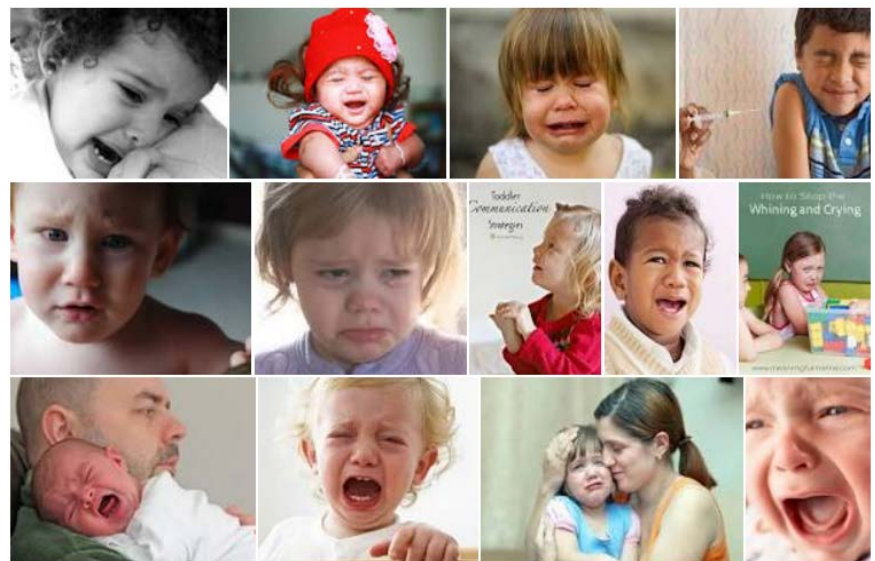

Figure 01: Images of Children Crying

Source: http://www.littleheartsbooks.com/tag/positive-parenting/

(Retrieved on 18th August, 2016)

The images depict a state of helplessness among children. "When children find themselves in a state of confusion and perpetual helplessness, they break loose in emotions and the result is crying” (Miceli and Franchi, 2003)

\section{Appendix B}

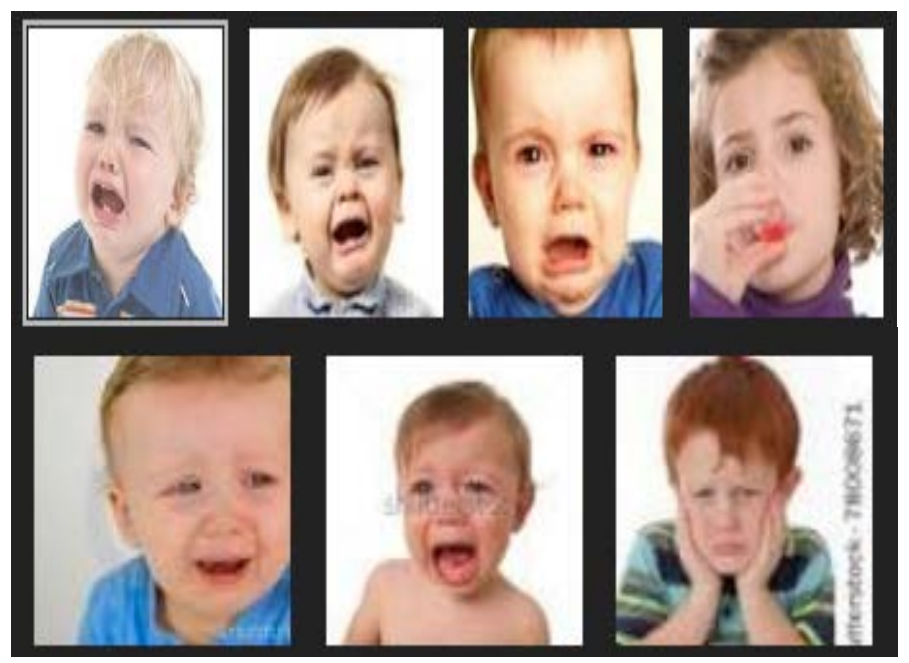

Figure 02: Breath-Holding Spells in Children (Images of Children Panting)

Source: www.raisingchildren.net.au (Retrieved on $18^{\text {th }}$ August 2016) 
The images depict breath-holding spells (panting) in children. "Panting among children expresses tamper tantrum, a way of expressing emotional distress and is characterized with intense anger” (Potegal and Davidson, 2003).

\section{Appendix C}
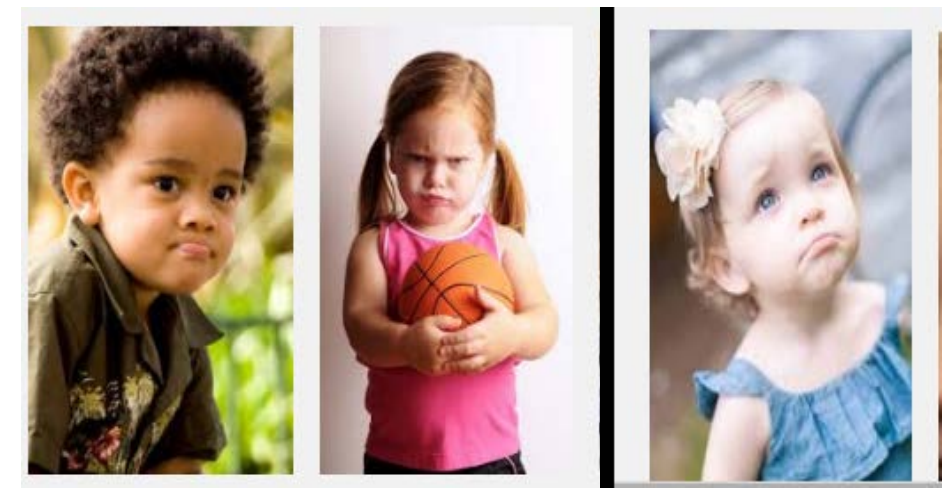

Figure 03: Images of Children Pouting

Source: http://www.littleheartsbooks.com/tag/positive-parenting/

(Retrieved on 18th August, 2016)

The images depict children pouting. "Pouting is common among children, due to several factors, one of which is lack of intelligence to express themselves in a healthy way" (Magher, 2015).

\section{Appendix D}

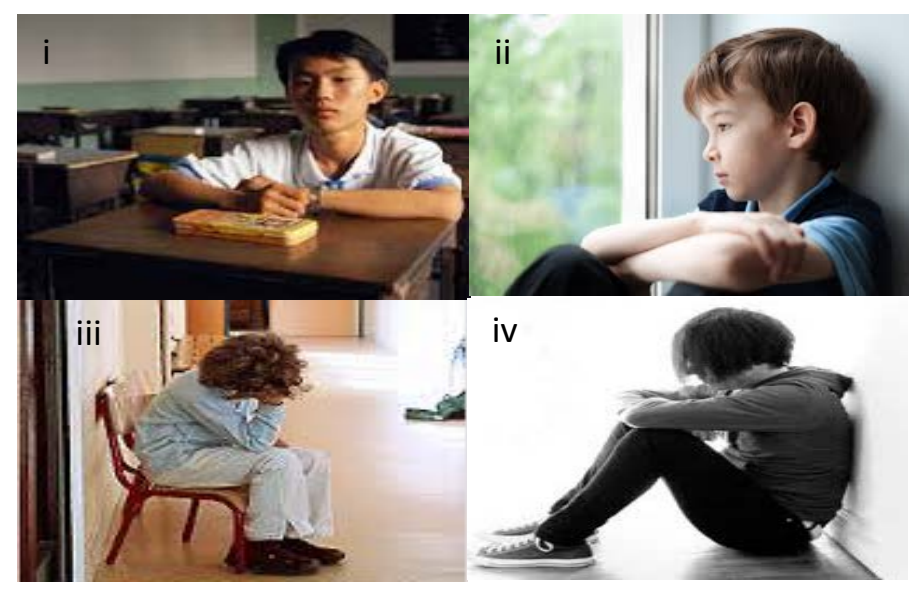

Figure 04: Images of Children Withdrawing

Source: i. www.kinderart.com; ii. www.childdevelopmentinfo.com; iii. www.adderalladdictionsupport.com; 
The images depict children withdrawing. "The expression of social withdrawal among children can be a way of expressing themselves when they are sad" (Fox et.al, 2005).

\section{Appendix E}

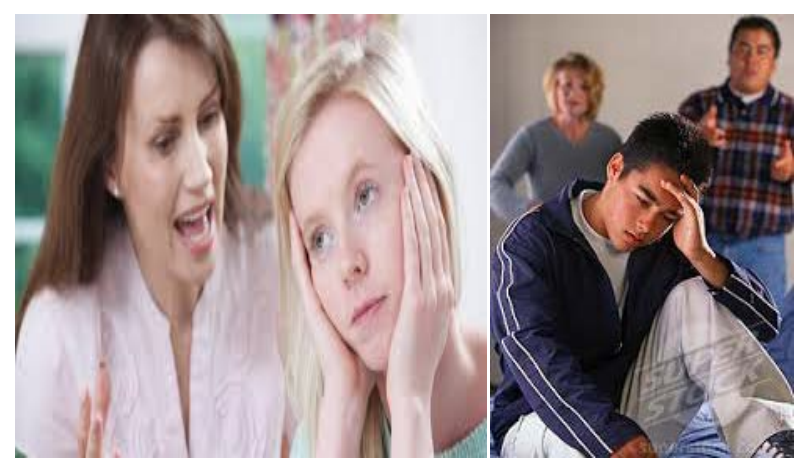

Figure 05: Images of Children's Silent Treatment

Source: www.onlineparentingcoach.com(Retrieved on 18th August 2016)

The images depict children's silent treatment. "The silent treatment is used by children as a way to freeze you out to get you to leave them alone” (Lefman, 2010).

\section{Appendix F}

\section{Author's Details}

Victor Monday Dibie, PhD

B.Sc. Business Administration, Ambrose Alli University, Ekpoma, Nigeria

M.Sc. Marketing, University of Lagos, Akoka, Lagos, Nigeria

PhD. Marketing, Ebonyi State University, Abakaliki, Nigeria

Area of Specialization: Consumer Behaviour (with special interest on children)

Fellow, Institute of Policy Management Development (FIPMD)

Fellow, Strategic Institute for Natural Resources and Human Development (FRHD)

Member, Global Institute for Research and Development (MGIRD)

Member, National Institute of Marketing of Nigeria (MNIMN) 


\section{References}

Arul, M. and Vasudevan, V. (2016), "Influence of children on parents' buying behaviour, The Cost and Management, 44(1), 19-24

Bandura, A. (1997). Self-Efficacy: The Exercise of Control. Freeman:New York

Bandura, A. (1986). Social Foundations of Thought and Actions: A Social Cognitive Theory. Eagle-woods Cliffs, NJ. Prentice Hall.

Boivin, M., Hymel, S. and Bukowski, W.M. (1995). The roles of social withdrawal, peer rejection and victimization by peers in predicting loneliness and depression mood in children, Developmental Psychopathology, 765-785

Cartwright C., and Gibson K. (2012). Experiences of family parenting allowances in stepfamilies. Paper presented at the $12^{\text {th }}$ Australian Institute of Family Studies Conferences, Melbourne. AIFS

Casement P. (1990). Further Learning from the Patient. London, 113-114

Chaudhary, M., and Gupta, A., (2012). Exploring the influence strategies used by children: An empirical study in India, Management Research Review, 35 (12), 1153-1169.

Child Development Institute (1999). Know your child better by leaning the ages and stages of child development, CDI:America,1-8

Coplan, R.J., Prakash, K., O’Neil, K. and Armer, M. (2004). Do you want to play? Distinguishing between conflicted shyness and social disinterest in early childhood, Developmental Psychology, 40, 244-258.

Corfman, K.P.,and Lehmann, R. L. (1987). Models of cooperative group decision- making and relative influence: investigation of family purchase decisions, Journal of Consumer research, 13 (June), 1 - 13.

Crying Images of Children. http://www.littleheartsbooks.com/tag/positiv e-parenting/ (Retrieved Online: 18 August 2016)

Daniel, T.L.S, Quizhi, X., and Li, L. (2015). The impact of family intactness on family relationship, parental control and parentchild relational qualities in a Chinese context. Frontiers in Pediatrics, 2(149), 1-7.

Davidson, T. (2006). Temper tantrums. In k. Krapp and J. Wilson (eds). Gale Encyclopedia of Children's Health: Infancy through Adolescence, 1803-1804.

Deuschi, G., Bain, P.G., Brin, $\mathrm{M}$ and Adhoc Scientific Committee (1998). Consensus statement of the movement disorder society on tremor, Movement Disorder, 13, 2-23.

DeVellis, R. F. (1991). Scale Development: Theory and Application. London: Sage Publications.

Dibie, V.M. (2017). Children's influence strategies on family purchase decision making in Umuahia, Abia State, Southeast, Nigeria (A study of selected household products). PhD Thesis Unpublished, Abakaliki: Dept. of Marketing, EBSU. 1 205.

Doheny, K. (2011). Why we cry: The truth about tearing up, Webb MD (Retrieved: 04 June, 2016)

Federal Republic of Nigeria Official Gazette (2007). "Legal notice on publication of the details of the breakdown of the national and state provisional totals, 2006 Census". (en.m.wikipedia.org/w).Retrieved Online: 01 July, 2010. 
Fox, N.A., Henderson, H.A., Marshall, P.J., Nicholas, K.E., and Ghera, M.M. (2005). Behavioural inhabitation: Linking biology and behaviour within developmental framework, Developmental Psychology, 56 (235-262).

Frey, W.H. (1985). Crying: The Mystery of Tears, Personal Page. In Langseth, M., Frey, W.H. and William H. (1985) edn. Do Animals Shed Emotional Tears. Crying the Mystery of Tears. Winston Press,Minneapolis, Minn.,135-139

Ganong, L.H. and Coleman, M. (2004). Step Family Relationships: Development, Dynamics and Interventions. New York, Kluwer Academic/Plenum Publishers

Gazelle, H. and Ladd, G.W. (2003). Famous solitude and peer exclusion. A diathesis stress modelling of internalizing trajectories on childhood, Child Development, 75 (825849).

Glands, K., Rimer, B.K., and Lewis, F.M. (2002). Health Behaviour and Health Education: Theory Research and Practice. San Francisco, Wiley and Sons.

Human Ethology Newsletter (1989). The origin of crying and tears, 5 (10), 5-6

Kendig, S.M. and Bianchi, S.M. (2008). Singles, cohabiting and married mothers' time with children. Journal of Marriage and Family, 70, 1228-1240.

Landseth, M., Frey, W.H. and William, H. (1985). Do animals shed emotional tears? Crying: The mystery of tears. Winston Press,Minneapolis, Minn., 135-139

Lee, C.K.C and Collins, B.A. (2000). Family decision making and coalition patterns. European Journal of Markeing, 34(9/10), 1181-1198. http://doi.org/10.1108/0309-0560-010342584.x

Lehman, J. (2010). Empowering Parents, Child Behaviour, Help
Lehman, J. (2010). Moody kids: How to respond to pouting, whining and sulking, www.empoweringparents.com (Retrieved on $14^{\text {th }}$ November, 2020)

Leikin, J. and Lipsky, M. (2003). Tantrum. In J. Leikin and M. Lipsky (eds). American Medical Association. Complete Medical Encyclopedia, New York: Random House, 1191.

Levickis, P, Reilly, S., Girolametto, L., Ukoumunne, O.C. and Wake, M. (2014). Maternal behaviours promoting language acquisition in slow to talk toddlers: Prospective community-based study. Journal of Developmental and Behavioural Piediatrics, 35(4), 274-281.

Loudon, D. L., and Della - Bita, A. J, (1993). Consumer Behavior, 4 edn..U.S.: McGraw Hill International.

Magher, M. (2015). Why Children Pout, Livestrong Foundation,US

McCurdy, M., Kunz, G.M and Sherridan, S.M. (2006). Temper trantrums. In G.G. Bear and K.M. Minke (eds). Children's Needs III: Development, Prevention and Intervention, 149-157, Washington: National Association of School Psychologists.

McNeal, (1998) in Thomson, E. S., Laing, A. W., and Mckee, L. (2007). Family purchase decision making: Exploring child influence behaviour, Journal of Consumer Behaviour, 6 (182-202).

MedHelp, (2000). Baby panting like a dog, Maternal and Child Health. www.medhelp.org, (Retrieved Online: 05 June, 2016)

Miceli, M. and Castelfranchi, C. (2003). Crying: Discussing the basic reasons and uses, New Ideas in Psychology, 21 (3), 247273

Miller, N.E. and Dollard, J. (1941). Social Learning and Imitation. New Haven, C.T. Yale University Press. 
National Population Commission (2006). National Population and Housing Census, Priority Table, Vol. V, Table DS7. Distribution of Population (Age 10 and Above) by Sex, Age Groups and Marital Status, NPC:Abuja

Nwokoye, N.G. (2000). Modern Marketing for Nigeria: Principles and Practice. Onitsha, Africana First Publishers Plc.

Omodafe, U. P. (2015). Determinants of children's role in family buying decisionmaking: The Case of South-South Nigeria, International Journal of Management Science and Business Administration, 1(7), 30-38. http://doi.org/10.18775/J.18495664/5419.2014.17.1003.x

Pajares, F. (2002). Overview of Social Cognitive Theory and of Self-efficacy. http:www.uky.edu (Retrieved on $14^{\text {th }}$ November, 2020)

Panting Images of Children. www.raisingchildren.net.au (Retrieved on 18th August, 2016)

Paraga, I.M. (1990). Determinants of food consumption. Journal of American Dietetic Association, 90, 661-663.

Passali, D, Lauriello, M., Bellussi, L., Passali, G.C., Passali, F.M. and Gregori, D. (2010). Foreign body inhalation in children: An update. Acta Otorhinolaryngol Ital, 30(1), 27-32.

Patel, U. (1993). Crying behaviour and psychiatric disorder in adults, A comprehensive review, Psychiatry, 34(3), 206-211.

Pietrangelo, A. (2019). How to respond when someone gives you the silent treatment, Healthcare. www.healthlife.com (Retrieved on $14^{\text {th }}$ November, 2020)

Potegal, M., Davidson, R.J. (2003). Temper tantrums in young children, Journal of Development and Behavioural Paediatrics 24 (3): 140-147
Pouting Images of Children. http://www.littleheartsbooks.com/tag/positiv e-parenting/ (Retrieved Online: 18 June, 2016)

Roy, B. (2008). Solving health and behavioural problems from birth through preschool, Child Development, 157-162.

Schneider, A. (2014). Silent treatment: Preferred weapon of people with narcissism. Good Therapy, www.goodtherapy.org (Retrieved on $14^{\text {th }}$ November, 2020)

Silent Treatment Images of Children... www.onlineparentingcoach.com. (Retrieved Online: 18 August, 2016)

Tusian, P.C. and Thunjhnuwala, B. (2010). Business Statistics: A Self Study Text Book. New Delhi, S. Chandler and Company Limited.

Vasa, R.A., and Pine, D.S. (2006). Anxiety Disorders. In Esau C. Editor Child and Adolescent Psychopathology. Theoretical and Chemical Complications. Routledge Taylor and Francis:New York78-112.

Wallen, N. E. \& Fraenkel, J. R. (2001). Educational Research: A Guide to the process. London: Lawrence Erlbaum Associates.

Walter, C. (2006). Why do we cry? Scientific American Mind, 17(6), 44

Withdrawing Images of Children. www.kinderart.com, www.childdevelopmentinfo.com, www.adderalladdictionsupport.com, www.adderalladdictionsupport.com. (Retrieved Online: 18 August, 2016)

Yamane, T. (1967). Elementary Sampling Theory, Eaglewood Cliffs, Prentice Hall Inc.:New Jersey. 